\title{
Pavlovo razumevanje postave in del postave v Pismu Galačanom. The New Perspective on Paul in nov pogled na Pavlov odnos do judovstva
}

\author{
Paul's Understanding of the Law and Works of the \\ Law in Galatians. The New Perspective on Paul \\ and a New Look at Paul's Relationship to Judaism
}

Izvleček: $\mathrm{V}$ prispevku bodo predstavljeni ključni elementi raziskovanja novega pogleda na Pavla (The New Perspective on Paul), ki so Pavla in njegovo teologijo močneje postavili v kontekst judovstva njegovega časa. Celovit pogled na Pavla daje nov zagon tudi odnosom med Judi in kristjani. V izbranih odlomkih Pisma Galačanom bomo preverili Pavlovo razumevanje postave, del postave, opravičenja po veri, kot temelj novega življenja. Pavel tako kot njegovi judovski nasprotniki v Galaciji postave nikoli ni razumel ozko kot pot za dosego opravičenja, temveč kot temeljno Božje razodetje, ki je vzpostavilo izvoljeno Božje ljudstvo. Pokazati želimo, da lahko nov pogled na Pavla da tudi razvoju krščansko-judovskih odnosov nov zagon in novo vsebino. Pavlova in judovska teologija gradita na skupnem temelju razodetja, ki izvira iz Božjega klica človeka v obljubljeno deželo, to je v novo zavezno občestvo z njim. Ta klic je izziv tudi za sodobne odnose med Judi in kristjani. ${ }^{1}$

Ključne besede: Apostol Pavel, Nov pogled na Pavla, Pismo Galačanom, postava, Tora, nomos, dela postave, opravičenje, vera, judovstvo, dialog, ekumenizem

\begin{abstract}
The paper presents the key elements of exploring the New Perspective on Paul, which placed Paul and his theology more strongly in the context of the Judaism of his time. A holistic view of Paul also gives new impetus to the relationship between Jews and Christians. In selected passages from the Epistle to the Galatians, we will examine Paul's understanding of the Law, works of the Law, and of justification by faith, as the foundation of a new life. Paul, like his Jewish opponents in the Galatians, never understood the Law narrowly as a way to achieve justification, but as a fundamental revelation of God that established God's chosen people.
\end{abstract}

1 Prispevek je nastal kot rezultat dejavnosti raziskovalnega programa P6-0262 Judovsko-krščanski viri in razsežnosti pravičnosti, ki ga je sofinancirala Javna agencija za raziskovalno dejavnost Republike Slovenije iz državnega proračuna. 
We want to show that a new view of Paul can also give new impetus and new content to the development of Christian-Jewish relations. Paul's and Jewish theology builds on a common foundation of revelation that stems from God's call of man to the promised land, i. e. into a new covenant communion with him. This call is also a challenge for modern relations between Jews and Christians.

Key Words: Apostle Paul, New Perspective on Paul, The Epistle to the Galatians, faith, Law, Torah, Righteousness, works of the Law, Judaism, dialog, ecumenism

\section{Uvod}

Ob pripravi obeleževanja 500-letnice začetka reformacije so 31. oktobra 1999 v Augsburgu predstavniki Svetovne zveze luteranskih Cerkva in predstavniki Rimskokatoliške cerkve podpisali skupno izjavo glede nauka o opravičenju, ${ }^{2}$ s katero so luteranski in katoliški teologi potrdili »skupne poglede na naše opravičenje z Božjo milostjo po veri v Jezusa Kristusa» (SI 5). S tem pomembnim teološkim dokumentom so potrdili temeljno soglasje glede teme, ki je pred 1850 leti pretresala Pavlove skupnosti in pripomogla k hitri rasti krščanskih Cerkva, saj je bila vera predstavljena kot temeljna pot za vstop v zavezo z Bogom, pred 500 leti pa je razdelila teologijo Cerkve na protestantsko in katoliško. Čeprav je bila izjava deležna tudi kritik, da je določene vidike predstavila precej na splošno, drugih pomembnih tem ekumenskega dialoga, npr. razumevanje Cerkve in evharistije, pa se sploh ni dotaknila (Söding 2016, 168-174; Valentan 2017, 144-147), so podpisniki tudi sami priznali, da »izjava sicer ne vsebuje vsega, kar uči vsaka od Cerkva o opravičenju, toda razločno se vidi v njej soglasje o temeljnih resnicah nauka o opravičenju in obenem možnost različnih smeri razvoja brez doktrinalnih obsodb«(SI 5). S tem pa je bil narejen velik napredek v razvoju ne le ekumenskega gibanja, ampak tudi krščanske teologije kot take. Izjava je spodbudila potrebo po poglobljenem bibličnem študiju ključnih pavlinskih teoloških in kristoloških tem, kar pa je dalo nov zagon tudi judovsko-krščanskemu dialogu. (Söding 2016, 168-176) Okrepila se je zavest, kako pomembno je vedno znova z različnimi metodami in viri preverjati interpretacijo judovskih in krščanskih virov, na katerih temelji ne samo sodobna teologija in ekleziologija, temveč tudi pogled na človeka in družbo.

2 Slovenski prevod: Skupna izjava glede nauka o opravičenju (Svetovna luteranska zveza - Papeški svet za pospeševanje edinosti kristjanov 1999, 71-88). 
K premikom v ekumenskem gibanju in v medreligijskem dialogu je gotovo bistveno prispevalo poglobljeno biblično raziskovanje Pavlovih pisem in njihovega zgodovinskega konteksta v zadnjem stoletju, ki se je v sedemdesetih letih prejšnjega stoletja predvsem v protestantskem okolju uveljavilo pod imenom The New Perspective on Paul (NPP). V novem pogledu so raziskovanje Pavla spet močneje vpeli v kontekst judovske tradicije, to je Pavlovega helenističnega judovstva in njegovega razumevanja Stare zaveze, ter poskušali Pavlovo teologijo osvoboditi različnih kasnejših krščanskih, helenističnih in sholastičnih interpretacij. Ni namreč dvoma, da je npr. Avguštinova in Lutrova interpretacija Pavlovega razumevanja greha, milosti in opravičenja, ki je pogosto temeljila na negativnih stereotipih o antičnem judovstvu in na specifičnih ekleziološih konceptih, imela velik vpliv na antijudovsko interpretacijo Pavlove teologije. (Schröter 2013, 144) V prispevku bomo najprej predstavili nekaj ključnih poudarkov v razvoju NPP, nato pa na podlagi analize Gal 2,15-17; 3,1-9 podrobneje osvetlili Pavlovo razumevanje postave, del postave in vere za dosego Abrahamovega sinovstva.

\section{Prispevek The New Perspective on Paul k razvoju judovsko-krščanskega dialoga}

Nedvomno je zadnje stoletje raziskovanja Pavlove teologije bistveno zaznamovala teza Rudolfa Bultmanna, da je nauk o opravičenju iz vere, ki ga Pavel najbolj jasno predstavil v Pismu Galačanom in Rimljanom (Gal 2,16; Rim 3,28), njegovo osrednje teološko in kristološko oznanilo ter dejansko središče njegove kristologije in biblične teologije (1933, 261-262). Vse, kar je Pavel povedal teološkega, naj bi se po Bultmannu odražalo v njegovem oznanilu opravičenja. Ta interpretacija Pavlove teologije je nekaj desetletij prevladovala tako v protestantskih kot v katoliških bibličnih raziskovanjih, čeprav je bilo slišati tudi drugačne glasove. Številni so opozarjali, da je taka interpretacija Pavlove kerigme preozka ter izrazito antropološka in individualistična, predvsem pa da premalo upošteva tako realno zgodovinsko osebo Jezusa Kristusa kot tudi zgodovinsko, to je judovsko ozadje Pavlove osebnosti in njegove teologije. S poudarjanjem soteriologije na račun kristologije se je Bultmann dejansko oddaljil od »resnice evangelija« (Gal 2,5.14), ki želi pripeljati do občestva s Kristusom in človeku v njem podariti deležnost novega življenja ( Gal 2,20). Resnica evangelija ni sad teološke spekulacije o Kristusu, temveč oznanila konkretnega Kristusovega 
dogodka, to je njegove smrti in vstajenja kot edinega vira za človekovo opravičenje in novo življenje. (Söding 2000, 221-222) Pavel je to izkusil v lastnem življenju in se je za oznanilo te resnice evangelija, ki vsem odpira dostop do novega življenja, boril z jeruzalemskimi voditelji judovskih kristjanov, ki so hoteli dopolniti Pavlovo oznanilo z Mojzesovo postavo.

Tudi že pred Bultmannom so znani biblicisti izražali dvome, da je nauk o opravičenju po veri brez del postave res osrednji teološki koncept Pavlove teologije odrešenja. Bultmann je tako očital kolegu Williamu Wredetu, da ima Pavlov nauk o opravičenju za nekaj postranskega, zgolj za neko »borilno veščino«(»Kampfeslehre«), ki ga je Pavel uporabil v boju proti judaistom, ki so zanikali možnost, da bi lahko tudi pogani imeli dostop do odrešenja po veri v Jezusa Kristusa (1933, 261). Tudi Albert Schweitzer je zagovarjal tezo, da je osrednje Pavlovo oznanilo v resnici mistično, saj oznanja notranje občestvo s Kristusom - »biti v Kristusu (Rim 3,24; 6,11; 8,1.39; 12,5; Gal 2,4.17; 3,28; 5,6) - kot stanje novega, odrešenega Življenja (Schröter 2013, 145).

Med najodmevnejše predhodnike NPP spada tudi švedski ekseget Nove zaveze Krister Stendahl, ki je v svojih raziskavah v šestdesetih letih kritiziral izkrivljeni zahodni način branja pavlinskih pisem (1963, 199-200). Pavlova interpretacija na zahodu je vse od Avguština preko srednjeveške pobožnosti in Luthra do Bultmanna sledila tendenci zoženega individualnega razumevanja človekove krivde in opravičenja, ki zadeva v prvi vrsti posameznika. Po Stendahlu je Pavel odpiral veliko bolj temeljno vprašanje odrešenja, to je sprejetje novega življenja, in ne zgolj ozko vprašanje o opravičenju in veljavnosti del postave. Ko Pavel v Flp 3 najbolj celovito spregovori o svojem življenju pred sprejemom krščanskega poklica in nove vizije, ne omenja, da bi imel predtem v judovstvu kakršnekoli težave pri izpolnjevanju postave. Nasprotno, pohvali se, da je bil »po pravič-

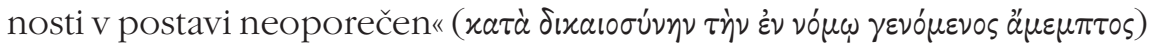
(3,6b). Njegovo srečanje z Jezusom Kristusom pred Damaskom (Apd 9,19) ni spremenilo tega dejstva. Zanj to srečanje ni pomenilo spreobrnjenja v vesti, saj pravi zgolj, da pozablja, kaj je za njim $(3,13)$, in sprejema novo preroško poslanstvo, to je ponesti oznanilo odrešenja v Kristusu tudi poganom. Vloga postave kot »vzgojiteljice« ( $\pi \alpha \iota \delta a \gamma \omega \gamma o ̀ s)$, ki je človeka »vodila

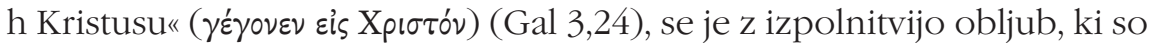
bile dane Abrahamu, zaključila. Pavlove izjave o opravičenju zato niso 
izjave o človeški grešnosti in njegovi potrebi po odrešenju na splošno, temveč so izraz prepričanja, da so se v Kristusu izpolnile obljube odrešenja, ki so bile preko Abrahama dane vsem narodom. Pavel priznava "prednost Judov«, ki je v tem, da so bile prav njim zaupane Božje besede, in to jim ne bo nikoli preklicano, tudi če so neposlušni (Rim 3,1-4). Druge prednosti pa po Pavlu Judje nimajo, saj pri odrešenju tudi postava ne more pomagati, ker so pred njo enako krivi kot pogani ali pa še bolj. Pavlove izjave o opravičenju je tako treba razumeti bolj v ekleziološkem kot v antropološkem smislu, saj gre Pavlu predvsem za to, da predstavi v Kristusu pot do Boga, ki je odprta tako za Jude kot za pogane. Njegovo antitezo »vera/dela postave« je po Stendhalu treba razumeti znotraj konkretnega zgodovinskega konteksta razprave z njegovimi judovskimi nasprotniki, ne pa kot neko temeljno trditev o človekovem odrešenju. (1963, 200-201)

Dejanski začetnik NPP je ameriški ekseget Parish Sanders, ki se je v sedemdesetih letih posvetil raziskovanju palestinskega judovstva med letom 200 pr. Kr. in 200 po Kr. v rabinski, apokrifni in kumranski literaturi ter v svojem temeljnem delu Paul and Palestinian Judaism predstavil vpliv le-tega na Pavla. Opozoril je na izkrivljeno podobo judovstva, na kateri je gradila srednjeveška in Lutrova interpretacija Pavla, ki ni upoštevala dejanskega Pavlovega zgodovinskega okolja. (1977, 1-29) Kritičen je do vnosa Lutrove interpretacije Božje pravičnosti in del postave v Pavlovo teologijo, ki vztraja pri interpretaciji Pavla vse do današnjih dni. (1977, 474-477; 2016, 51-83) Sanders poudarja, da Pavel dejansko ne zanika, da bi lahko postava človeka opravičila, trdi pa, da je postala po Kristusovem odrešenjskem dogodku v polnosti uveljavljenja in s tem presežena (Rim 3,31). Pavel ne išče kot Luter rešitve, kako je mogoče izpolniti postavo, da bi našel potem odgovor v pravičnosti iz vere, ampak razmišlja ravno obratno - izhaja iz milosti in razmišlja o tem, kako bi ta dosegla slehernega človeka in mu odprla pot do odrešenja. Protestantska interpretacija Pavlove antiteze med milostjo in deli postave izhaja po Sandersu iz popačene podobe judovstva kot religije postave, ki je Lutrove polemične izjave proti delom pravičnosti interpretirala v zgodovinskem kontekstu srednjeveške Cerkve in jih na tak nezgodovinski način obrnila na Pavlovo polemiko z judovstvom njegovega časa. V judovstvu postava ne pomeni zgolj zbirke predpisov, ki jih mora človek izpolniti, da bi lahko vstopil v zavezo, ki jo je Bog sklenil z Izraelom, ampak predstavlja celotno vsebino zaveze in je kot taka znamenje pripadnosti Božjega ljudstva Bogu. (Schröter 2013, 147) 
Sanders upravičeno trdi, da Pavel ne razume judovske postave napačno (kot načina za dosego odrešenja), in dokazuje, da za Pavla postava nikoli ni bila mišljena kot vstopna zahteva in pot za dosego Božjega načrta. Po Sandersu vloga postave $\mathrm{v}$ judovstvu ni v tem, kako bi koga pripeljala v zavezo z Bogom, temveč v tem, kako lahko kdo, ki je izvoljen in v zavezi, ostane v njej. (1977, 17-48) Za Pavla pa izvoljenost ali zaveza ali izpolnjevanje postave po odrešenjskem dogodku Jezusa Kristusa ni več pogoj za dosego odrešenja oziroma pripadnosti Božjemu ljudstvu, temveč to doseže po deležnosti v Kristusovi smrti in vstajenju (Rim 6,4). Sanders govori zato o dveh različnih religioznih strukturah ("patterns of religion«), o judovski in o religiozni strukturi pavlinske teologije. Pavel naj bi tako po svojem spreobrnjenju ne imel težav z judovsko usmerjenostjo na postavo, torej z judovsko religiozno strukturo, temveč s tem, da judovski voditelji niso prepoznali končnega Božjega razodetja v Jezusu Kristusu. (1977, 12-19) Sandersova zasluga je nedvomno v tem, da je pokazal, da je treba Pavla interpretirati znotraj konteksta judovstva njegovega časa. V tem kontekstu naj bi tudi Pavel ločeval med postavo kot Božjim razodetjem, ki vzpostavlja zavezno ljudstvo, in deli postave, ki ohranjajo njihovo istovetnost in zagotavljajo ločenost od preostalih narodov. Veliko je pripomogel h korekciji popačene podobe judovstva, ki ga je ustvarila srednjeveška reformistična teologija, pri tem pa je bil deležen tudi kritik, da je poenostavljal antično judovstvo, ki je bilo veliko bolj razvejeno in večstransko, kot ga je Sanders predstavil. (Carson 2001, 1-5)

Med Sandersove kritike in hkrati pomembne raziskovalce NPP spada James G. G. Dunn, ki je v svojem prispevku iz leta 1983 The New Perspective on Paul pokazal, da Pavel ni imel namena pustiti judovskega religioznega sistema nedotaknjenega in preprosto postaviti nasproti temu nekega novega, lastnega, temveč si je prizadeval za novo interpretacijo Svetega pisma in judovske tradicije. Strinja se s Sandersom, da Pavel postave vsekakor ni zavračal, kritiziral pa je judovsko razumevanje postave kot institucije, s katero se judovstvo ograjuje od drugih narodov in s tem zamejuje pripadnost Božjemu ljudstvu nasproti vsem preostalim narodom. Pavel si je močno prizadeval za odprtje judovstva drugim narodom, saj bi prav na ta način postava le še pridobila svoj pomen kot nosilka razodetja Božje volje za življenje ljudi. (Dunn 2005, 107-110) Pavel svojo kerigmo in misijonsko poslanstvo vedno znova utemeljuje iz pisem judovske tradicije in uporablja pri tem tudi judovska načela interpretacije Svetega pisma, 
vendar pa išče v luči Kristusovega odrešenjskega dogodka novo in celovitejšo odrešenjsko interpretacijo. Dunn na podlagi raziskav kumranskih

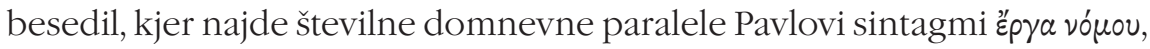
dokazuje, da se Pavlov izraz ne nanaša na izpolnjevanje judovske postave, temveč predvsem na tiste predpise, s katerimi se judovstvo ograjuje od preostalega sveta. ${ }^{3}$ Gre predvsem za zapoved obreze, za predpise o čisti in nečisti hrani, sobotne predpise in praznične koledarje (Gal 4,10), ki jih Dunn imenuje »Označevalci identitete« (»identity markers«) $(2005,109)$. Pri interpretaciji Pavlove teologije je zato treba resno vključiti tudi sociološke okoliščine, v katerih so se rojevale prve krščanske skupnosti, in položaj takratnega judovstva, ki še zdaleč ni imelo enotnih strateških poudarkov. To je veljalo tako za judejske skupnosti, kjer je bilo zelo živo in razvejeno judovsko mesijansko gibanje, kot za skupnosti v helenistično-rimskih diasporah, od koder izvira tudi Pavel. Tam so imeli gotovo specifični vidiki postave, ki so ločevali judovstvo od ostalega sveta, pomembno vlogo pri ohranjanju judovske identitete.

\section{Pavlovo razumevanje postave s posebnim poudarkom na Pismu Galačanom}

V okviru novega pogleda na Pavla so se vedno znova zastavljala vprašanja, ali je Pavel judovsko postavo kot razodetje Božje modrosti za ljudstvo zaveze pravilno razumel, jo je poenostavil in zožil, ali jo je razumel predvsem Z vidika judovske diaspore in helenizma (Dunn 1998, 131-133). Pavlovo helenistično ozadje je gotovo vplivalo na njegovo interpretacijo. V pismih, ki jih je pisal grško govorečim skupnostim v grščini, je hebrejski termin תּוֹרָ, ki pomeni učenje, navodila v najširšem smislu, 118-krat prevedel

3 Dunn zelo poudari novejše odkritje kumranskega fragmenta 4QMMT Miqsat Ma'aseh Ha-Torah (Dela

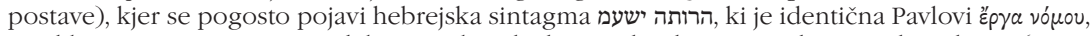
ter sklepa na tesne povezave dela jeruzalemske krščanske skupnosti s kumranskimi krogi (2005, 333-339). Tudi v Pravilu skupnosti najdemo to obliko: »Vse tiste, ki niso všteti v njegovo zavezo, je treba izločiti, nje same in vse, kar je njihovo. Mož svetosti se ne sme opirati na nobena dela ničevosti, kajti ničevost so vsi, ki ne poznajo njegove zaveze [...] Ko se kdo oklene zaveze, da bo delal v skladu Z vsemi temi zakoni in se pridružil svetemu občestvu, naj v skupnosti preiščejo njihovega duha od človeka do človeka glede njegove dojemljivosti in njegovih dejanj po postavi (הרותה ישעמ)."(1QS 5,18.20-21) Večina sodobnih raziskovalcev je kritična do hipotez o domnevnih Pavlovih stikih s kumransko tradicijo; glej Hofius (2006, 272-285).

4 Glej razprave Bird in Sprinkle (2008, 355-358); Dunn (1990, 215-241; 2005, 131-141); Räisänen (1987, 128-161); Sanders (1977, 1-12); Seifrid (2010, 20-35). 
z grškim terminom vópos, ${ }^{5}$ ki ima prevladujoč legalistični pomen (zakon, nauk, postava). Pavel nikoli ni natančno definiral termina vómos, ker je lahko predpostavljal, da ga bralci poznajo. Ker je Pavel poznal tudi izvirne hebrejske tekste postave, se je gotovo soočil tudi s problematiko prevajanja ת z vónos v grškem prevodih Septuaginte, ki je marsikdaj zožila hebrejski pomen ת.רְוֹ Glede na svojo rabinsko izobrazbo je dobro poznal klasično judovsko učenje, po katerem תרז sestavljajo postava, preroki in pisci, in zato moramo tudi njegovo uporabo in razumevanje termina vónos za postavo razumeti dovolj široko. (Gutbrod 1966, 1047) Dejansko njegova pisma izkazujejo zelo prilagodljivo uporabo tega termina, saj z njim poimenuje Mojzesovo postavo (npr. Rim. 5,13-14; Gal 3,17; 1 Kor 9,8; 2 Kor 3,7-11), navaja preroke in psalme kot besede postave (Rim 3,10-18; 1 Kor 14,21), ponekod pa se vópos nanaša kar na celotno izraelsko biblično tradicijo (npr. Gal 4,21.30). Za Pavla termin vónos vsekakor ni omejen na zakon ali postavo v pravnem smislu, ampak se, čeprav z različnimi odtenki, nanaša na verodostojno izraelsko tradicijo, zasidrano v razodetju na Sinaju. Prav zaradi te tradicije ima termin vópos tudi specifični pomen, ki daje Judom po Pavlu posebni status (Rim 2,1; 1 Kor 9,20-21; Gal 2,15) in jih ločuje od poganov, torej od vsega preostalega človeštva. (Räisänen 1987, 16-41)

V tej luči želimo posebej preveriti Pavlove antiteze med »deli postave«in »vero v Kristusa«v Gal 2,16; 2,21; 3,2-5.9-12; 5,4 (Rim 3,27-28; 4,2-5.14). Ali Pavel $s$ kritiko nasprotja med vero in postavo kritizira postavo kot tako ali določeno razumevanje postave? Je postava zanj res konkurenčni soteriološki princip, judovska pot do odrešenja? (Räisänen 1987, 162-191)

\subsection{Dela postave kot znamenje zaveze (Gal 2,15-17)}

Eno ključnih mest za Pavlovo razumevanje postave (vóros), del postave

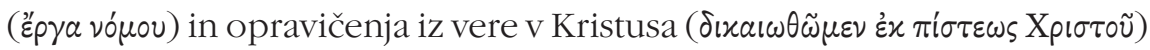
in s tem njegove soteriologije in nauka o opravičenju se nahaja v Gal 2,1517 (Hofius 2006, 271; Räisänen 1987, 162). Podobna formulacija se pojavi

5 Od 118 pojavov termina vómos pri Pavlu jih je $74 \mathrm{v}$ Rim in $32 \mathrm{v}$ Gal, preostali pa so v 1 Kor in Flp.

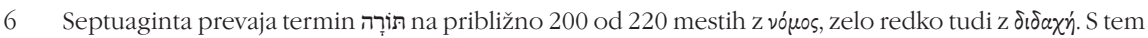
poenotenim prevodom se je pomen termina תiּ zlasti v starejših tekstih zožil na račun semantičnega razvoja v mlajših besedilih po eksilu. Predvsem se to vidi pri prevodu množinskega termina תורות v edninsko obliko vó ros (npr. 2 Mz 16,28; 18,16.20; Iz 24,5; Jer 26,4; Prg 3,1). (Gutbrod 1966, 1039) 
tudi v naslednjem odlomku (3,2.5.10), ko Pavel v svojo argumentacijo vključi Abrahamovo vlogo v odrešenjski zgodovini.? Raziskovalci NPP so dovolj utemeljeno dokazali, da Pavlova polemika proti »delom postave« ne pomeni polemike proti dobrim delom. ${ }^{8}$ Nasprotno, svoja občestva spodbuja, naj

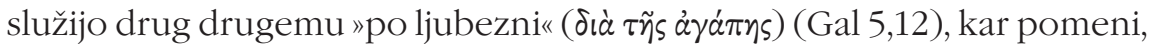

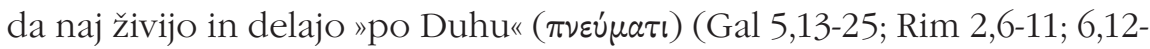
13), „Saj v Kristusu Jezusu nič ne velja ne obreza ne neobreza, marveč vera,

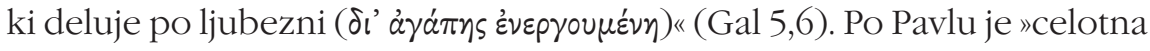
postava izpolnjena $v$ eni zapovedi: 'Ljubi svojega bližnjega kakor samega sebe' "(Gal 5,14). Pavel tako z bibličnim dokazom iz postave (3 Mz 19,18) utemelji, da vere v Kristusa ni brez del ljubezni. Iz tega lahko sklepamo, da kontrast med »deli postave« in »vero v Kristusa« ne pomeni kontrasta med »delati« in "podrediti se«, temveč med »delati za nagrado« in podrediti se Božjemu daru, to je milosti (Rim 4,2-5; Ef 2,8-9). (DeSilva 2018, 225; Dunn 1998, 354-355)

Pavlovo specifično razumevanje sintagme ép $\gamma \alpha$ vópou je treba najprej iskati v širšem kontekstu njegovih pisem, še posebej Rim in Gal. Že na začetku Gal je podano ključno soteriološko izhodišče za razumevanje te sintagme, ko je predstavljen Kristus, »ki je daroval sam sebe za naše grehe, da bi nas iztrgal iz sedanjega hudobnega sveta, kakor je hotel Bog in naš Oče» $(1,4)$. Božje opravičenje je za Pavla aktivno delovanje Boga Očeta, ki v Jezusu Kristusu pridruži človeka novemu odrešenemu življenju in ga s tem, po judovski terminologiji, naredi za pravičnega. Opravičenje torej prihaja po "veri $v$ Jezusa Kristusa" ( Kristusa« (2,16), ${ }^{9}$ po katerem deluje Bog Oče. Brez volje Boga Očeta bi torej človek ostal podvržen zasužnjujoči moči »sedanjega hudobnega sveta«

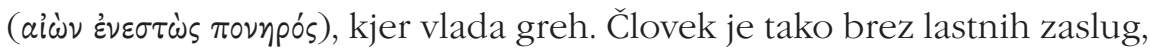
"po veri«, ki ga odpira Božji milosti, pridružen Kristusovi daritvi na križu

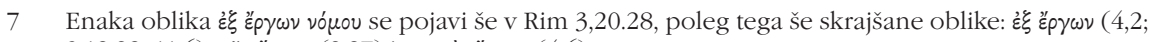
$9,12.32 ; 11,6), \tau \tilde{\omega} \nu$ है $p \gamma \omega \nu(3,27)$ in $\chi \omega p$ is है $p \gamma \omega \nu(4,6)$.

8 Glej Dunn (1998, 355-350, 365; 2005, 111-130); Sanders (1983, 159), ki poudarja, da v Gal konflikt med »delati« in »verovati« preprosto ni prisoten; Moo $(1983,99)$ je mnenja, da Pavel očitno kritizira »dela postave« ne zaradi "postave«, ampak kot »dela».

9 Gre za tipično pavlinsko konstrukcijo genitivnega objekta (prim. Rim 3,22.26; Gal 2,16.20; 3,22; Flp 3,9), ki jo je mogoče interpretirati na način, da je Jezus »objekt« vere, ki opravičuje, ali da je Jezus "subjekt«vere, da torej človeka opravičuje njegova "vera« v Boga Očeta, njegova odrešenjska daritev. Matera $(1999,94)$ zagovarja prepletanje obeh vidikov vere, saj človek po veri v Jezusa Kristusa prihaja tudi do Kristusove vere. 
(2,19b). Na ta način je Kristus človeka »odkupil od prekletstva postave tako, da je za nas postal prekletstvo $(3,13)$. S tem je tudi človek "po postavi

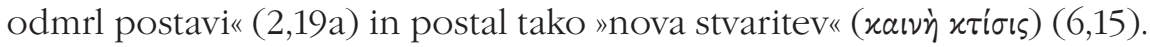
Kakršnakoli človeška »dela postave« $\mathrm{v}$ tem procesu torej niso odločilna.

Pavel prav na podlagi izkustva, ki ga je imel ob sporu s Kefom v Antiohiji ugotavlja, da dela ne vodijo do opravičenja, ker ne pripeljejo do občestva, ki je temeljni sad Božjega delovanja po Jezusu Kristusu (1 Kor 1,9). (Matjaž 2019a, 177-178) Do prihoda Jakobovih ljudi v Antiohijo so namreč tam kristjani iz poganstva in kristjani iz judovstva, torej tudi Kefa, Pavel in Barnaba, živeli v zglednem občestvu. Pavlu so vodilni judovski kristjani iz Jeruzalema očitali preveliko popustljivost do poganskih spreobrnjencev, ki so očitno brez upoštevanja judovskih predpisov glede druženja in uživanja hrane dobili prostor pri skupni mizi. Spor s Kefom v Antiohiji - Kefa se je ob prihodu Jakobovih ljudi hotel umakniti iz tega občestva - predstavlja uvod $\mathrm{v}$ temeljno teološko razpravo $\mathrm{v}$ Gal o pomenu postave in $\mathrm{s}$ tem tudi o odnosu med kristjani in Judi. Pavel začne svojo argumentacijo

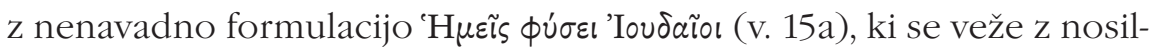
nim glagolom drugega stavka é Judje, $[. .$.$] smo začeli verovati v Kristusa Jezusa.« Pavel s tem poudari de-$ jansko povezavo med »biti Jud « in »verovati v Jezusa», saj očitno tudi Judje

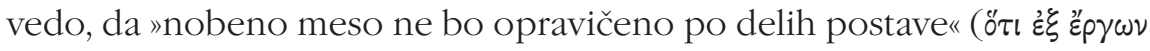

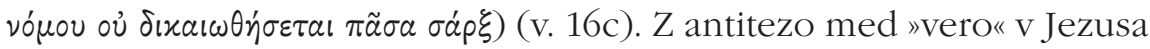
Kristusa in »deli postave« izpostavi najprej dejstvo, da obstajajo tudi Judje, ki verujejo v Jezusa Kristusa, to so najprej on sam, Kefa in ostali judovski kristjani v Antiohiji. Obenem pa s tem ne zamolči osnovne razlike, ki ločuje Jude od poganov: Judje so "po naravi« izvoljeni in imajo postavo, pogani pa "po naravi« grešniki, ker nimajo postave, ker je ne poznajo in ne živijo po Božjih zakonih. (Mussner 1974, 167) Gre za tipično izraelsko zavezno terminologijo, ki je odraz zapovedi ločevanja med pogani in Judi. Pri tem je pomemben Pavlov poudarek, da tako Judje kot krščanski verniki delijo skupno vero, da je opravičenje izključno Božje delo. Očitno tu ne gre samo za neko hipno Pavlovo spoznanje, ampak za argumentirano izjavo. Stavek je namreč uveden s členico ö $\tau$, ki se pogosto pojavi v argumentacijah, ko uvaja neko splošno trditev oziroma neko izročilo. (Zerwick 1963, 418) Podobno konstrukcijo najdemo tudi v nadaljevanju razprave $(3,11)$, kjer je prav tako s členico ö $\tau \iota$ uvedena biblična argumentacija opravičenja po veri: »Da (ö $\tau \iota \delta \varepsilon \dot{)})$ se nihče ne more opravičiti pred Bogom s postavo, 
je očitno, kajti (ő $\tau$ ) pravični bo živel iz vere. " Pavel poudarja skupno prepričanje, da grešnika opravičuje samo vera v Boga, in se pri tem sklicuje na Ps 142,2 LXX (»Nihče, ki živi, ni pravičen pred tabo«) ter na Hab 2,4: »Pravični bo v svoji veri živel.«Podobno bo Pavel argumentiral tudi v Rim 3,20: »Kajti

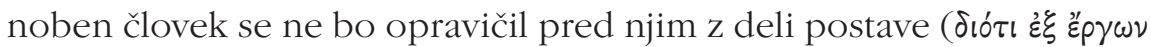

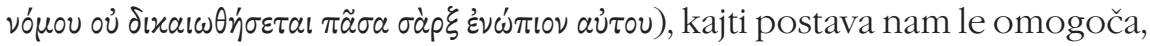
da spoznamo greh.«

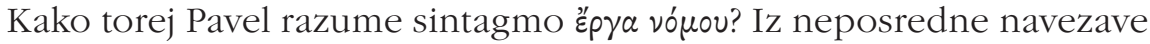
odlomka 2,15sl. na predhodni odlomek, kjer Pavel opiše svoj spor s Kefom v Antiohiji (2,11-14), ko mora braniti »resnico evangelija« ( $\tau \dot{\eta} \nu \dot{a} \lambda \dot{\theta} \theta \varepsilon ı \alpha \nu ~ \tau o \tilde{u}$ $\varepsilon \dot{a} \gamma \gamma \varepsilon \lambda$ íou) pred judaisti, to je pred »lažnimi brati«(2,3-5), ki so bili blizu Jakobu in jeruzalemski Cerkvi (v. 12), je mogoče sklepati, da so za Pavla »dela postave« najprej predpisi glede hrane in s tem povezana pravila o ločevanju od poganov. Predpisi glede čiste in nečiste hrane (5 Mz 14,321) so v prvi vrsti služili utrjevanju judovske identitete kot izvoljenega ljudstva, ki pripada samo Bogu in se s tem tudi loči od vsega preostalega sveta (3 Mz 20,22-26). (Dunn 1998, 354-356) Poleg predpisov o hrani pa je postava predpisovala še druga »dela«, ki so ločevala izvoljeno ljudstvo od drugih narodov. Med najbolj značilnimi je bila zapoved obreze, ki jo je prejel Abraham kot temeljno znamenje svoje pripadnosti zavezi (1 Mz 17,9-14). Tudi za Pavla je obreza glavno razpoznavno znamenje pripadnosti judovskemu ljudstvu (Rim 3,30; Gal 2,7-8; Flp 3,5). V smislu pričevanja pripadnosti Božjemu ljudstvu priznava, da je lahko obreza tudi »koristna" ( $ڤ \varnothing \lambda \varepsilon \tilde{\imath})$ (Rim 2,25), če je odraz izpolnjevanja postave. Abraham je namreč prejel znamenje obreze kot »pečat pravičnosti iz vere«(Rim 4,11). To je tudi argument, ki ga Pavel uporabi v nadaljevanju Pisma Galačanom, ko svari pred sprejetjem obreze. Obreza je znamenje pripadnosti ljudstvu postave in hkrati znamenje ločitve od vseh drugih, zato bi z njenim sprejetjem kristjani odpadli iz občestva s Kristusom (5,1-6) ter zatajili svojo novo identiteto v Kristusu, po katerem so bili osvobojeni tudi različnih nacionalnih spon in postali »nova stvaritev«(6,12-15). Dela postave torej Pavel razume povsem v skladu z judovskim prepričanjem, da ne gre za »orodje«, temveč za »znamenje« opravičenja. Dela postave so torej odgovor izvoljenega ljudstva na zavezo, ki jo je Bog sklenil z njimi, ter znamenje njihove posluš-

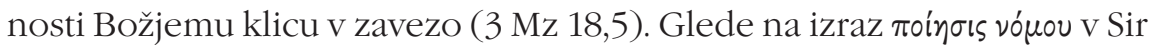
19,20, ki je morda edina direktna paralela Pavlovi sintagmi v kanonični literaturi (Hofius 2006, 309), je mogoče dela postave razumeti tudi kot 
odraz bogaboječega življenja človeka, predanega Božji zavezi in njenim zahtevam. Pred izkustvom Kristusa je Pavel tudi sam razumel dela postave kot ekskluzivni privilegij izvoljenih rodov Božjega ljudstva (Flp 3,3sl.). Po milostnem razodetju Božjega Sina (Gal 1,15-16), ko mu je bil zaupan evangelij odrešenja za vse narode, pa so dela postave izgubila svoj smisel in "jarem sužnosti« $(5,1)$ ter postala za kristjana celo znamenje »odpada od milosti« (5,4). S tem pa ne zanika njihovega pomena v kontekstu zaveze, še manj pa s tem omalovažuje pomen postave. James Dunn zato pravilno poudarja, da gre pri delih postave dejansko za »dela zaveze«. $(2005,101)$

\subsection{Vera kot vstop v Abrahamovo sinovstvo (Gal 3,1-9)}

Pavel želi v nadaljevanju pisma Galačanom dokazati, da so po veri v Jezusa Kristusa tudi oni postali dediči Abrahamovih obljub in torej izvoljeno zavezno ljudstvo. Zdi se, da so Pavlovi nasprotniki, ki so se pojavili v njegovih skupnostih po Galatiji, želeli vernike prepričati, da je poleg vere v Jezusa Kristusa treba sprejeti tudi obrezo in Mojzesovo postavo $(3,2)$, če želijo pripadati zavezi Božjega ljudstva Abrahamovih sinov (3,7). Tudi spreobrnjencem iz poganstva očita, da so spet podlegli »slabotnim in bednim prvinam«, kot je obhajanje dnevov, mesecev in letnih časov (4,9-10). Pri tem so bili očitno precej uspešni, saj ton pisma odraža Pavlovo zgroženost nad njihovo popustljivostjo. Konflikt se očitno vse do konca pisma ni polegel $(5,2-4 ; 6,11-13)$. Uvod v drugi del pisma $(3,1-5)$ ima enako retorično ostrino kot predtem uvod v celotno pismo $(1,6-10)$. Taka ostrina na eni ter odsotnost pohval in zahval na drugi strani sta nekaj posebnega v Palovih pismih in tudi sicer v takratni kulturi pisanja. ${ }^{10}$ Pavel tako stoji pred ključnim izzivom svoje kerigme v galačanskih Cerkvah, kako prepričljivo odgovoriti na vprašanja, kdo je resnični Abrahamov potomec in s tem dedič njegovih obljub (1 Mz 17,7). (Gundry 1985, 8-10) Njegovi nasprotniki, ki so mu očitali pomanjkljivo oznanjevanje, ker ni navajal na dela postave, so se sklicevali na Sinajsko zavezo (Gal 4,24-25), saj ta vsebuje številne obveze, ki jih je treba izpolniti za življenje v zavezi z Bogom. Pavel pa se po drugi strani sklicuje na $3 \mathrm{Mz}$ 18,5 in pri tem opominja, da vstop v to zavezo

10 Glej Pitta (2017, 151-165); Nanos (2002, 75-85) na podlagi sociološke analize dokazuje učinkovitost takega pristopa, ki namiguje na moč, sramoto in čast v takratni kulturi, ki je zelo cenila zmage in časti, poraze pa prezirala. Za čast so v tej kulturi pripravljeni žrtvovati in storiti marsikaj, da bi se izognili sramoti. Strah pred zasmehovanjem je tudi močan pozitivni dejavnik, saj ohranja vzpostavljeni red učinkoviteje kakor najbolj restriktivne in prisilne prepovedi. 
»ni iz vere, ampak: 'Kdor to izpolnjuje, bo živel od tega' (Gal 3,12); kdor pa tega ne izpolni - in nihče tega ne more izpolniti - bo podvržen prekletstvu (Gal 3,10; 5 Mz 27,26). Pavel v Gal 4,25 namiguje, da so se njegovi nasprotniki, judovski kristjani iz Jeruzalema, prepoznali kot dediči Sinajske zaveze in se predstavljajo za prave Abrahamove sinove. Pri tem pa dopuščajo možnost, da tudi pogani vstopijo v zavezno Božje ljudstvo, saj je Bog obljubil Abrahamu, da bodo po njem in njegovih potomcih blagoslovljeni vsi narodi (1 Mz 12,3; 18,8; 22,18; Gal 3,8). Prav zaradi tega so tudi začeli svoj "protimisijon « v Palovih galačanskih skupnostih. A prepričani so, da morajo za dosego te obljube galačanski spreobrnjenci iz poganstva biti tudi obrezani in sprejeti Mojzesovo postavo. (Hong 1994, 166-168) Očitno je Pavlovim nasprotnikom s tem argumentom uspelo prepričati številne Galačane, saj je med njimi vladal precejšen konflikt, ki je resno ogrožal na novo pridobljeno občestvo med njimi (Gal 5,13-18; 6,1-2.7-10).

Pavel celotni osrednji del pisma (Gal 3-4) posveti razvijanju argumentov, s katerimi želi zavrniti zavajanje nasprotnikov in ponovno pridobiti zaupanje Galačanov. V uvodnem delu (3,1-5), kjer po načelih grške retorike razvije dokazovanje (probatio), se sklicuje na njihovo osebno izkušnjo (pathos), da bi jih predramil in pridobil. ${ }^{11}$ Predoči jim njihovo začetno naklonjenost, ko so z vero sprejeli Duha in se je njihovo življenje spremenilo (5,13-25). Nagovori jih osebno z neobičajno krepkim izrazom:

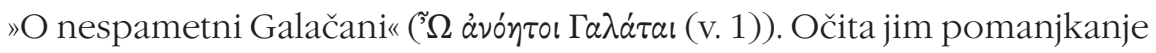
vpogleda v bistvo evangelija, ki jim je bil predstavljen z oznanilom križanega Kristusa. V pismu sicer ne razvije posebne kerigme o križu (ó $\lambda o ́$ os

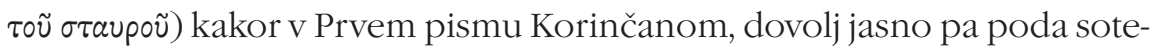
riološki temelj svojega oznanila $(1,4 ; 2,20)$. Jezik njegovega prepričevanja odraža že rahlo apokaliptični ton, ko se čudi nad prepričevalno močjo

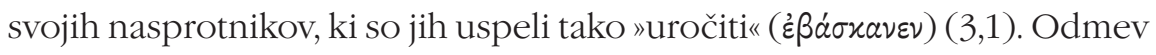
in komentar tega uvodnega dela lahko prepoznamo v 5,2-12. (Pitta 2009, 167) V sklepnem apelu (v. 5) se ponovno vrača k daru Duha, ki med njimi

11 Pavel je vešč grške retorike, ki izhaja iz Aristotelovega nauka o politiki, govorništvu in načinih dokazovanja (dialektike) ter umetnosti prepričevanja. Proces dokazovanja ali argumentacije (probatio) se glede na vrste argumentov, ki jih govornik uporablja, deli na logos, ki se dotika vsebine govora, argumentacije kot racionalnega dokaza in se pri Pavlu nanaša predvsem na Sveto pismo, ethos, ki zadeva govorca, njegov značaj, izkušnje in način obnašanja, ter pathos, ki zadeva izkušnjo poslušalca, ki jo govornik nagovarja, da prebudi psihološke in čustvene argumente in naklonjenost. Govorec mora upoštevati tako logične kot tudi čustvene vidike. (Kennedy 2001, 91-115) 
še deluje in jih vabi k premisleku, zakaj so se takrat dogajale med njimi tako veličastne stvari, "zaradi del postave ali zaradi poslušanja vere« ( $\xi^{\xi} \xi \xi \xi \gamma \omega \nu$

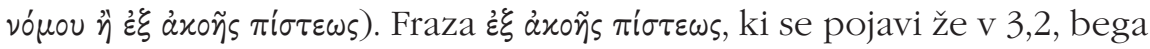
mnoge razlagalce. Tako ảxoń kot $\pi i \sigma \tau \iota s$ imata lahko namreč dva različna pomena: kot $\pi i \sigma \tau \varepsilon \omega \varsigma$ lahko pomeni dejanje poslušanja ali vsebino poslušanja, kot $\pi i \sigma \tau \iota s$ pa lahko pomeni dejanje vere ali vsebino vere, $\mathrm{v}$ tem primeru Pavlovo kerigmo. (Hong 1994, 170) Za določitev pomena fraze $\dot{\varepsilon} \xi \hat{\alpha} x \circ \tilde{\eta} s$

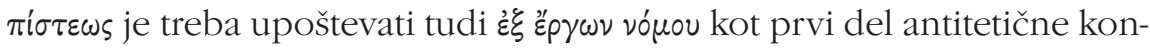
strukcije dveh genitivnih fraz. Nedvomno se ép $p a$ tu nanaša na človeško aktivnost, to je na izvrševanje del postave, čemur so Galačani očitno ponovno zapadli (4,10). (Williams 1989, 86) Tako moramo tudi besedo ảxoń razumeti v aktivnem smislu kot dejanje poslušanja. Za korektno določitev pomena besede $\pi i \sigma \tau \iota$ pa je nujno videti povezavo z v. 6, ki jo vzpostavlja prislov $x a \theta$ ìs in ki uvaja argument Abrahamove vere v naslednjem od-

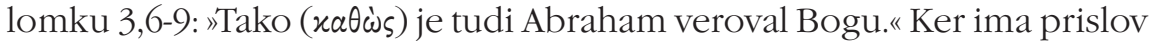
zelo širok semantični obseg in se v Novi zavezi pogosto pojavlja kot uvod v primerjanje, uvajanje bibličnih argumentov, označevanje podobnost dogodkov in stanj, ${ }^{12}$ lahko tudi tukaj sklepamo, da želi Pavel vzporejati izkustvo, ki ga imajo Galačani ob sprejemu Duha, in Abrahamovo izkustvo vere, ki ga je pripeljala do opravičenja (3,6-8). Tako kot je Abraham

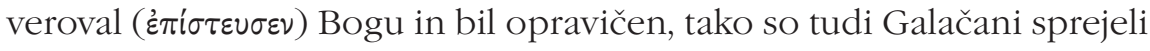

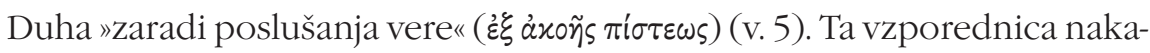
zuje, da se $\pi i \sigma \tau \iota \varsigma$ Galačanov v 3,2.5 nanaša tako kot Abrahamovo verovanje

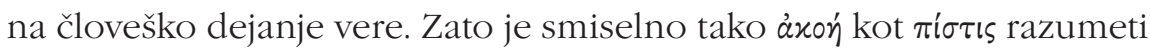
v aktivnem smislu. (Hong 1994, 171) Čeprav sta ti človeški aktivnosti precej podobni, se dopolnjujeta. Poslušnost ni preprosto dejanje ušes, ampak je kot vera »odgovor osebe«, to je odgovor "govorjeni besedi na način, ki je skladen z namenom govorca" (Williams 1989, 86). S to poslušnostjo veri so Galačani sprejeli Pavlovo oznanilo evangelija in izkusili moč Duha, čeprav niso poznali postave. S tem so bili podobni Abrahamu, ki je veroval v Božje obljube in bil opravičen zaradi vere vanj, ne da bi poznal postavo. To želi Pavel Galačanom v nadaljevanju tudi biblično utemeljiti.

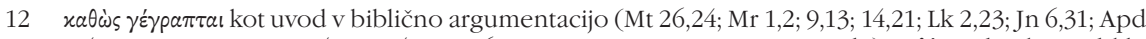
7,42; 15,15; Rim 1,17; 2,24; 3,10; 4,17; 8,36; 9,13; 10,15; 1 Kor 1,31; 2,9; 10,7 idr.); $x \alpha \theta \dot{\omega} \varsigma$ v absolutni obliki se pri Pavlu pojavi sicer samo v Gal 3,6 in gre torej za okrajšano uvodno obliko navajanja $1 \mathrm{Mz}$ 15,6; nekateri prevajajo prislov tudi kot »primer, zgled «: »Vzemimo za zgled (kot primer) Abrahama, ki je [...]«(Longenecker 1990, 112) 
Od 3,6 do 4,7 sledimo Pavlovemu razvijanju doktrine, ki jo je prej odpiral v obliki razprave z Galačani, ter njeni biblični argumentaciji. Včasih je težko slediti Pavlovi logiki, ker pogosto ne razvija misli do konca, preskakuje od enega argumenta k drugemu ali pa predpostavlja nekaj, česar bralec morda ne pozna. V celoti pa Pavel sledi jasni logiki utemeljevanja vere kot temeljne drže, ki je pripeljala Abrahama do sklenitve zaveze z Bogom in po kateri so tudi Galačani postali njegovi dediči. Osrednji lik prvega dela argumentacije $(3,6-9)$ je Abraham s svojo vero, na podlagi katere ga je Bog sprejel (opravičil) in sklenil z njim zavezo. Za Pavla je Abraham pomemben tudi kot oseba, zato tako številne omembe (3,6.7.8.9.14.16.18), saj je njegova osebna izkušnja poti vere model tudi za njegove potomce. ${ }^{13}$ Pavlov glavni argument o primatu poslušnosti veri nad poslušnostjo postavi je vzet iz pripovedi o sklenitvi zaveze in obljubi potomstva ( $1 \mathrm{Mz}$ 15,1-7): »Tako je Abraham veroval Bogu in mu je bilo to šteto v pravičnost." (v. 6; 1 Mz 15,6 LXX) Pavlovi nasprotniki so razumeli Abrahamovo vero kot zvesto pokorščino postavi, kar naj bi mu Bog »štel v pravičnost«, torej v zasluženje za sklenitev zaveze. Pavel pa razume $1 \mathrm{Mz}$ 15,6 drugače, saj ni navedeno nobeno delo postave kot pogoj za sprejem obljube, temveč zgolj vera. V kontekstu pripovedi o Abrahamovi veri ni mogoče zaslediti nobene implikacije o zaslugah. Zadoščalo je njegovo trdno zaupanje v Boga, da bo držal svojo obljubo in ga bo blagoslovil v potomcih (1 Mz 15,5). Njegova vera je bila v popolnem sprejemanju Božje obljube, tako je bila tudi zaveza odraz zastonjske Božje milosti. Odsoten je vsak namig o delih zasluženja. Obreza je omenjena šele v 1 Mz 17, in to kot posledica in znamenje te zaveze. Bog od Abrahama zahteva le brezpogojno vero v njegovo besedo, kar je za Pavla odločilni argument. (Vanhoye 2000, 80) Kasneje Pavel tudi pojasni, da vera in sklenitev zaveze nista mogli imeti nobene povezave s postavo, saj je ta prišla šele 430 let kasneje (Gal 3,17).

Zaključeno spodbudo in poziv, da se Galačani prepoznajo kot Abrahamovi sinovi, naveže Pavel neposredno na citat iz 1 Mz 15,6 o Abrahamovi veri: "Spoznajte torej, da so tisti, ki izhajajo iz vere, Abrahamovi sinovi« ( $\gamma \iota \nu \dot{\omega} \sigma x \varepsilon \tau \varepsilon$

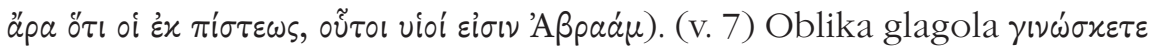

13 Abraham je pomemben lik tudi za esensko skupnost v Kumranu, o tem npr. priča kumranska apokrifna Geneza (1QapGen). V odnosu do Geneze (Pavlove podobe) je podoba Abrahama v tem apokrifu "prečiščena« z odstranitvijo oz. relokacijo mest, ki bi jih bilo mogoče interpretirati oz. razumeti v negativni luči, in dodajanjem novih z namenom dopolnitve kanoničnih pripovednih vrzeli. (Skralovnik 2018, 707-720) 
je lahko tako indikativna ("vi veste») kot imperativna ("spoznajte"). Večina ga interpretira kot imperativ (Mussner 1974, 216; Pitta 2009, 179), nekateri pa tudi kot indikativ, pri čemer se sklicujejo na helenistično literaturo, kjer pisec s frazo $\gamma \iota v \omega ́ \sigma x \varepsilon \tau \varepsilon$ ăpa zgolj spomni na to, kar je že splošno znano (Longenecker 1990, 114). Vsekakor ustvari Pavel s to direktno navezavo presenetljiv zaključek glede Abrahamovega sinovstva. Prvi del fraze (oi $\varepsilon \dot{x} \pi i \sigma \tau \varepsilon \omega \varsigma$ ) je logičen, ker nadaljuje temo vere in vzporeja način vere Abrahama z vero Galačanov. Gre torej za kategorijo ljudi, ki izhajajo

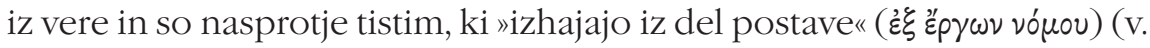

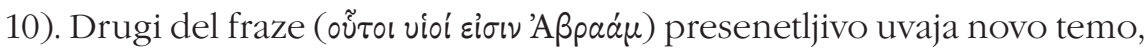
ki pa je za Pavla ključna, to je tema sinovstva. (Vanhoye 2000, 81) Vendar te teme tu ne razvije, ampak se vrne k njej v nadaljevanju, sicer z drugim

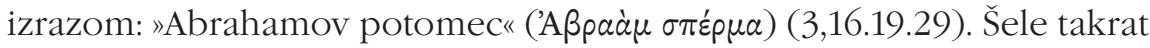
bo mogoče razumeti, da gre tudi v v. 7 za temeljno vprašanje, kako postati dedič obljub, ki so bile dane Abrahamu in njegovemu potomstvu, kako torej postati del Abrahamove družine, Abrahamov sin. Pavlovi nasprotniki so se očitno sklicevali na zapoved obreze v 1 Mz 17,13-14, ki vključuje tudi sprejetje celotne postave kot pogoj za sprejem Abrahamovega sinovstva. Glede na ta argument jim je gotovo mnoge uspelo prepričati, da so podvomili o Pavlovem oznanilu. Pavel zato tukaj prehiteva argumente in takoj zaključi, kar je sicer razvidno iz izvorne sklenitve Abrahamove zaveze, da človek postane Abrahamov dedič - sin - že po veri, ne da bi moral biti obrezan in opravljati dela postave. Zavedal se je, da ni gotovo, da bodo njegovi nasprotniki sprejeli njegov argument, po katerem je mogoče že preko delovanja Duha postati Abrahamov potomec. Dejansko so temu nasprotovali in se sklicevali na $1 \mathrm{Mz} 15,4$ ("Ne bo ta dedoval za teboj, temveč tisti, ki bo prišel iz tebe, bo tvoj dedič."), ki zahteva fizično potomstvo. Pavel se kasneje dotakne tudi tega njihovega argumenta in ga interpretira v luči aktualnih dogodkov: »Vi pa, bratje, ste kakor Izak otroci obljube. In kakor je takrat tisti, ki je bil rojen po mesu, preganjal tistega, ki je bil rojen po duhu, tako se dogaja tudi zdaj.«(4,28-29) V argumentaciji se sklicuje na globalni Božji načrt, ki ga razkriva Sveto pismo kot celota: „Pismo je predvidelo, da Bog opravičuje narode po veri.« $(3,8)$ Pri tem Pavel sicer

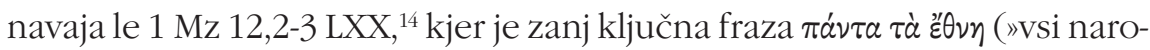

14 Grški prevod $1 \mathrm{Mz}$ 12,2-3 je narejen na podlagi masoretskega teksta v $1 \mathrm{Mz}$ 12,3 in $1 \mathrm{Mz}$ 18,18. Sicer se »Abrahamov blagoslov « pojavlja v LXX v številnih oblikah, npr. Ps 71,17; Sir 44,21. (Longenecker 1990, 215) 
di«), ki pa se nahaja še v drugih tekstih (1 Mz 18,18; 22,18; 26,4; 28,14). Vsi,

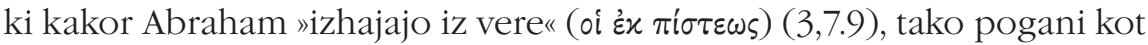
Judje, so deležni njegovega blagoslova in so torej z njim vred opravičeni (Rim 4,10-12). Po Pavlu je Bog že od samega začetka zgodovine odrešenja načrtoval vero, in ne postave, za edino sredstvo opravičenja. (Hong 1994, 170) To potrjuje galačanska izkušnja sprejetja Duha, ko je Duh v njihovih srcih rojeval vzklike: »Aba, Oče.« (4,6) S tem pa se je za Pavla uresničila tudi obljuba, ki je bila dana Abrahamu in na kateri temeljita tudi vera in zaveza judovskega ljudstva, da bo njegov potomstvo brezštevilno, torej odprto za vse.

\section{Nov pogled na Pavla in na odnos med Judi in kristjani}

Nov pogled na interpretacijo Pavla je najprej prinesel večjo pozornost na Pavlovo vpetost v judovske dileme tedanjega časa. Stara zaveza in judovstvo tako pridobita ključni pomen za razumevanje Pavlove teologije. Pavel sam se zaveda teološke ukoreninjenosti evangelijske kerigme v judovsko tradicijo, saj se v ključnih izjavah pogosto sklicuje na judovske svete spise in tradicijo, na tem gradi svojo argumentacijo in pri tem upošteva principe judovske hermenevtike ter grško-rimske retorike. (Matjaž 2019b, 924) Raziskave NPP so predvsem opozorile na nujnost upoštevanja zgodovinskega antičnega judovstva, ki se marsikdaj razlikuje tako od judovstva starega Izraela kakor od antične krščanske interpretacije judovstva, ki še ni imela zadostnega kritičnega dostopa do virov "palestinskega judovstva" Pavlovega časa (Sanders 1977, 33-59).

Že analiza izbranih odlomkov Pisma Galačanom, ki se dotikajo ključnih judovskih tem, kot so postava, zaveza, dela postave, vera in opravičenje, je pokazala, da med judovskim in Pavlovim razumevanjem ni bistvenih razlik. Ne vprašanje vere ne vprašanje opravičenja iz vere ni nekaj, po čemer bi se Judje in kristjani lahko med seboj ločevali. (Dunn 2005, 98) Pavlova terminologija opravičenja je del judovske terminologije zaveze, zato jo je za njeno razumevanje nujno vrednotiti v kontekstu zaveze. Biti opravičen pomeni v judovstvu najprej in predvsem biti del zaveze, ki jo je Bog sklenil s svojim ljudstvom, ne pa skupek opravljenih predpisov, ki bi šele odprli človeku vstop v to zavezo. (Sanders 1977, 312) Tako tudi Pavel ne razume opravičenja kot odgovor na vprašanje, kako lahko grešnik najde Božjo 
milost, temveč bolj na vprašanje, kako lahko pogani postanejo del Božjega ljudstva (Wright 2009, 136-140). S tem pa je vprašanje opravičenja, ki je bilo v zgodovini teologije in eksegeze večkrat samovoljno interpretirano kot najpomembnejše Pavlovo vprašanje, ki je ločevalo krščanstvo od judovstva, izgubilo osrednje mesto v Pavlovi teologiji. Vprašanje opravičenja po veri je v judovstvu treba interpretirati v konceptu milosti, ${ }^{15}$ pri Pavlu pa v konceptu občestva s Kristusom (Gal 2,4.17; 3,28; 5,6) in deležnosti novega življenja po njem.

Ključno vprašanje Pavlove teologije z ozirom na razvoj judovsko-krščanskih odnosov je gotovo pogled na Pavlovo razumevanje interpretacije postave. Res že samo prevajanje hebrejskega termina ת ת grškim vómos ne izrazi vedno kompleksne judovske semantike in predstavlja za eksegete vedno velik izziv. Vendar Pavel svoje teologije nikoli ne predstavlja na sistematično-dogmatski, temveč na epistolarno-kerigmatični način, zato je tudi njegovo razumevanje postave večplastno in dinamično ter prilagojeno retoričnim zahtevam. Iz analize izbranih mest, kjer se pojavi tema postave v Gal, je očitno, da Pavel njenega pomena ne zožuje. Ne gre za vprašanje izpolnjevanja določenih del ali pokorščine posameznim zapovedim, s čimer bi si človek zagotovil Božjo naklonjenost, temveč za te-

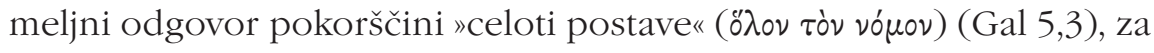
"podreditev Božji pravičnosti«(Rim 10,3), ki se v postavi razodeva kot zastonjska Božja izvolitev izvoljenega ljudstva. Pavel torej ne razume postave kot neko posebno pot za dosego opravičenja. Tako so tudi dela postave odgovor izvoljenega ljudstva na zavezo, ki jo je Bog sklenil z njimi, ter znamenje njihove poslušnosti Božjemu klicu v zavezo (3 Mz 18,5). Dela postave niso alternativa dobrim delom, kakor je zmotno izpostavil Luther in se je kasneje razvilo v glavno zablodo reformne teologije (Bultmann 1958, 264), ki je močno poškodovala tudi krščansko judovske odnose. (Dunn 2005, 101) Pavel in njegovi judovski nasprotniki v Galileji so si bili namreč edini, da človeka opravičuje samo Bog po njegovi brezpogojni veri. Zahteva Pavlovih nasprotnikov za obrezo poganskih spreobrnjencev je bila postavljena kot dodatni pogoj, ki naj ga verni pogani izpolnijo, če želijo vstopiti v Abrahamovo zavezo. Pavel je argumentirano dokazal,

15 Judovstvo prvega stoletja je bilo religija milosti, vendar je bilo razumevanje koncepta milosti zelo različno. Barclay $(2015,67-75)$ definira šest različnih vrst milosti z ozirom na to, ali je "skladna" $S$ človekovimi prizadevanji ali pa ta prizadevanja "prehiteva«. 
da to ne ustreza prvotni Božji zamisli, ki je predvidela samo vero kot vstop v Božjo zavezo (Gal 3,8), torej kot edino pot opravičenja.

\section{Sklep}

Apostol Pavel ostaja inspiracija vedno bolj pristnemu in partnerskemu judovsko-krščanskemu dialogu. Iz poglobljenega proučevanja apostola Pavla v njegovem celovitem teološkem in zgodovinskem kontekstu lahko izpostavimo dve paradigmi, ki naj prispevata k poglabljanju in razvoju odnosa med kristjani in Judi. Prva je pot »od posameznosti do občestva«. Tako Pavel kot judovstvo postavljata v svoje izhodišče in središče vero v Boga, ki kliče ljudstvo v občestvo z njim. Vera in pot v to občestvo sta sad Božje zvestobe, njegovega milostnega klica (Rim 11,29; 1 Kor 1,9; Gal 1,15). Temeljni odnos zaveze - občestva je bil tako vzpostavljen "po veri«, ki rešuje tako Jude kot kristjane in jih dela Božje sinove. To temeljno resnico Pavel tako močno poudari, da ob njej zbledijo vse še tako pomembne konfesionalne, nacionalne ali človeške posebnosti (Gal 3,26-29), ki bi ločevale, in se vzpostavlja neko temeljno občestvo, ki vključuje drugega in zmaguje nad posameznostjo. »Kajti niti obreza nič ne velja niti neobreza, ampak nova stvaritev. Nad vsemi pa, ki bodo živeli po tem pravilu, bodita mir in usmiljenje, kakor tudi nad Božjim Izraelom." (Gal 6,15-16) Iz tega izhaja druga paradigma, ki vodi »od ločevanja do pričevanja«. Kakor se je spor v Antiohiji razrešil z vzpostavitvijo občestva na podlagi skupnega temelja v Božjem razodetju ( Gal 2,9), tako so tudi danes kristjani in Judje postavljeni pred skupni izziv, kako pričevati svetu za Boga zaveze in njegov odrešenjski načrt. Na ta skupni izziv opozarja tudi izjava ortodoksnih rabinov Izpolnjevati voljo našega Očeta v nebesih, ki je bila objavljena ob 50-letnici koncilskega dokumenta Nostra aetate in predstavlja velik premik v krščansko-judovskih odnosih (Ahrens 2017, 53). V njej rabini ugotavljajo in potrjujejo, da imajo kristjani in Judje veliko več tega, kar jih združuje, kot tistega, kar jih ločuje. Sodelovanje ni samo vljudnostna gesta, temveč nuja, ki izhaja iz skupne teološke perspektive. Zavezuje jih obljuba Vsemogočnega o trajni zavezi s človekom. Za to oznanilo morajo Judje in kristjani skupaj pričevati, »da bo vse človeštvo klicalo njegovo Ime« (Den Willen unseres Vaters im Himmel tun 2016, 91). Po apostolu Pavlu se namreč»Bog ne kesa svojih milostnih darov in svojega klica» (Rim 12,29). 


\section{Kratice}

LXX Septuaginta, grški prevod Stare zaveze

NPP The New Perspective on Paul

QS Kumranski rokopis, Pravilo skupnosti

SI Skupna izjava glede nauka o opravičenju

\section{Reference}

Ahrens, Jehoschua. 2017. Den Willen unseres Vaters im Himmel tun: $\mathrm{Zu}$ Kontext, Entstehung und Rezeption der Erklärung orthodoxer Rabbiner und ein kurzer Ausblick auf die Zukunft des Dialogs. V: Hin zu einer Partnerschaft zwischen Juden und Christen, 53-79. Berlin: Metropol Verlag.

Barclay, John M. G. 2015. Paul and the gift. Grand Rapids, Michigan: William B. Eerdmans Publishing Company.

Bird, Michael F., in Preston M. Sprinkle. 2008. Jewish Interpretation of Paul in the Last Thirty Years. Currents in Biblical Research 6/3: 355-376.

Bultmann, Rudolf. 1933. Die Christologie des Neuen Testaments. V: Glauben und Verstehen, Zv. 1, 245-267. Tübingen: J. C. B. Mohr.

- - -. 1958. Theologie des Neuen Testaments. Tübingen: J. C. B. Mohr.

Carson Donald, A., in Peter T. O'Brien, ur. 2001. Justification and variegated nomism. Zv. 1, The complexities of second temple Judaism, 1-5. Tübingen: Mohr Siebeck.

Den Willen unseres Vaters im Himmel tun: Hin zu einer Partnerschaft zwischen Juden und Christen. Erklärung orthodoxer Rabbiner zum Christentum vom 3. Dezember 2015. 2016. Freiburger Rundbrief 23/2: 88-91.

DeSilva, David A. 2018. The Letter to the Galatinas. Grand Rapids: William B. Eerdmans

Dunn, James D. G. 1990. Jesus, Paul and the Law: Studies in Mark and Galatians. London: John Knox Press.

- - -. 2005. The New Perspective on Paul: Collected essays. Tübingen: Mohr Siebeck.
- - -. 1998. The Theology of Paul the Apostle. Grand Rapids: Eerdmans.

Gundry, Robert H. 1985. Grace, Works, and Staying Saved in Paul. Biblica 66: 1-38.

Gutbrod, Walter. 1966. vónos. ThWNT IV: 1029-1077.

Hofius, Otfried. 2006. Werke des Gesetzes. Untersuchungen zu der paulinischen Rede von den ERGA NOMOU. V: D. Sänger in U. Mell, ur. Paulus und Johannes: Exegetische Studien zur paulinischen und johanneischen Theologie und Literatur, 271-310. Tübingen: Mohr Siebeck.

Hübner, Hans. 1980. Das Gesetz bei Paulus: Ein Beitrag zum Werden der paulinischen Theologie. Göttingen: Vandenhoeck, Ruprecht.

Hong, In-Gyu. 1994. Does Paul Misrepresent the Jewish Law? Law and Covenant in Gal. 3:1-14. Novum Testamentum 36: 164-182.

Kennedy, George A. 2001. Klasična retorika ter njena krščanska in posvetna tradicija od antike do sodobnosti. Ljubljana: Založba ZRC.

Kumranski rokopisi. 2006. Prevod, uvodi in opombe Janez Zupet; spremna beseda Jože Krašovec. Ljubljana: Svetopisemska družba Slovenije.

Longenecker, Richard N. 1990. Galatians. Waco: Word Books.

Luteransko-rimskokatoliška komisija za edinost. 2017. Od konflikta do skupnosti. Ljubljana: Družina.

Matera, Frank J. 1992. Galatians. Collegeville: Liturgical Press. 
Matjaž, Maksimilijan. 2019a. Občestvo kljub različnosti. Pavlovo razumevanje koinonie v Pismu Galačanom (Gal 2,9). Edinost in dialog 74/1: 175-193.

- - - 2019b. Uporaba Stare zaveze v retorični argumentaciji Prvega pisma Korinčanom in njen pomen za razumevanje odrešenjske modrosti. Bogoslouni vestnik 79/4: 923-935.

Moo, Douglas J. 1983. Law, »Works of the Law", and Legalism in Paul. Westminster Theological Journal 45: 73-100.

Mussner, Franz. 1974. Der Galaterbrief. Freiburg: Herder.

Nanos Mark D. 2002. The Irony of the Galatians: Paul's Letter in FirstCentury Context. Minneapolis: Fortress Press.

Pitta, Antonio. 2009. Lettera ai Galati: Introduzione, versione e commento. Bologna: Edizioni Dehoniane.

- - - 2017. Retorica epistolare della Lettera ai Galati? Bilanci e prospettive. Rivista biblica 65/1-2: 149-172.

Räisänen, Heikki. 1987. Paul and the Law. Tübingen: Mohr Siebeck.

Sanders, Parish. 2016. Comparing Judaism and Christianity: Common Judaism, Paul, and the Inner and the Outer in Ancient Religion. Minneapolis: Fortress Press.

- - -. 1977. Paul and Palestinian Judaism: A Comparison of Patterns of Religion. Philadelphia: Fortress Press.

- - -. 1983. Paul, the Law, and the Jewish People. Philadelphia: Fortress Press.

Schröter, Jens. 2013. The New Perspective on Paul - eine Anfrage an die lutherische Paulusdeutung? Lutherjahrbuch 80: 142-158.

Seifrid, Mark A. 2010. The new perspective from Paul. Southern Baptist Convention 14/3: 20-35.
Skralovnik, Samo. 2018. Podoba Abrahama v kumranski apokrifni Genezi (1QapGen). Bogoslovni vestnik 78/3: 707-720.

Söding, Thomas. 2000. Christologie und Rechtfertigungslehre: Zur Hermeneutik der paulinischen Soteriologie. V: Udo Schnelle, Thomas Sodding in Michael Labahn, ur. Paulinische Christologie: Exegetische Beiträge, 220-245. Göttingen: Vandenhoeck \& Ruprecht.

- - - . 2016. Die „Gemeinsame Erklärung zur Rechtfertigungslehre« heute gelesen: Eine exegetische Kritik in ökumenischer Absicht. V: Udo Swarat in Thhomas Söding, ur. Heillos gespalten? Segensreich erneuert? 500 Jahre Reformation in der Vielfalt ökumenischer Perspektiven, 158-180. Freiburg: Herder.

Stendahl, Krister. 1963. The Apostle Paul and the Introspective Conscience of the West. Harvard Theological Review 56: 199-215.

- - - 1977. Paul Among Jews and Gentiles. Philadelphia: Fortress Press.

\section{Svetovna luteranska zveza - Papeški svet za} pospeševanje edinosti kristjanov. 1999. Skupna izjava glede nauka o opravičenju. Vedinosti: Ekumenski zbornik 1999: 71-88.

Valentan, Sebastijan. 2017. Katoliška cerkev in dialog z luterani - na poti k edinosti. Edinost in dialog 72: 141-153.

Vanhoye, Albert. 2000. Lettera ai Galati: Nuova versione, introduzione e commento. Milano: Paoline.

Williams, Sam K. 1989. The Hearing of Faith: AKOE PISTEŌS in Galatians 3. New Testament studies 35: 82-93.

Wright, Nicholas Thomas. 2009. Justification: God's Plan E Paul's Vision. Downers Grove: InterVarsity.

Zerwick, Maximilian. 1963. Biblical Greek. Roma: Pontificio Istituto Biblico. 